\section{First GM insect field trial planned in US}

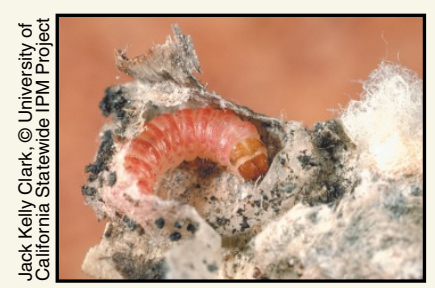

Entomologists from the USDA and the University of California at Riverside have applied for a USDA permit to conduct the first US field test of a GM insect in Arizona. Pectinophora gossypiella, the pink bollworm, is a lepidopteran pest whose larvae cost cotton farmers \$24.6 million dollars in prevention, control, and yield losses each year. The primary method to control the pest is to release waves of sterile adults into the environment. If they successfully compete with the wild population to reproduce, the resulting offspring are sterile, thus ultimately decreasing subsequent larval infestation. However, there is no way to assess how many sterile offspring have been produced and so, to ensure effectiveness, approximately 60 sterile insects are released for every 1 that is wild-an inefficient and costly procedure. Because the transgenic bollworm expresses a jellyfish green fluorescent protein during the larval stage, the proportion of sterile larvae can be "seen," enabling cotton growers to tailor the subsequent release of sterile insects accordingly. It is hoped this will reduce the number of sterile insects released up to twelve-fold. Before a permit is granted, the USDA Animal and Plant Health Inspection Service will consider comment on an environmental assessment, which is expected to be made public in April.

\section{HUPO is underway}

February 8 marked the official launch of the Human Proteome Organization (HUPO), a worldwide consortium to efficiently elucidate the complex interactions of human proteins. According to Ian Humphrey-Smith, founding chair in Pharmaceutical Proteomics at the Universiteit Utrecht (The Netherlands) and CEO of Glaucus Proteomics (Bunnik, The Netherlands), the consortium aims to eliminate "the animosity between the public and private sectors [that surrounded] the Human Genome Project" by coordinating the involvement of at least 24 companies and public institutions. Initial members include Celera Genomics (Rockville, $\mathrm{MD}$ ), the Scripps Research Institute (La Jolla, CA), Harvard University's Proteome Institute (Cambridge, MA), and Yamaguchi University (Yamaguchi, Japan). HUPO will hold its inaugural meeting from April 2-4 in McLean, VA, to define the organization's goals, discuss current rival projects such as the Protein Structure Initiative (Nat. Biotechnol. 18, 1127, 2000), and seek nominations for a president. As HumphreySmith doesn't yet know whether HUPO will receive any public funding, it is likely the data generated will be commercialized. $\mathrm{He}$ also says that his first HUPO project will be to create an antibody for each and every human gene within 4-7 years.

$A B$

Business and Regulatory News Briefs written by Aaron Bouchie, Sylvia Davidson, Liz Fletcher, Jeffrey L. Fox, KS Jayaraman, Sabine Louët, and Eric Niiler.

\section{British Biotech's MMPIs flop yet again}

On February 13, British Biotech (BBIOY; Oxford, UK) revealed the clinical failures of two matrix metalloproteinase inhibitors (MMPIs) as cancer treatments, prompting a $10 \%$ fall in its share price to $\$ 3.38$ two weeks after the news. Marimastat tallied its sixth and seventh phase III failures-both for small-cell lung cancer-since first tanking in June 1999 (Nat. Biotechnol. 17, 117, 1999); BB-3644 failed its first phase I study by having no clear advantage over marimastat at its maximum tolerated dose. There are two remaining marimastat trials-for nonsmall-cell lung cancer and pancreatic cancer-under a $\$ 60$ million deal struck in September 1999 with Schering-Plough (Kenilworth, NJ). BBIOY Chief Financial Officer Tony Weir says the assumption is that MMPIs in cancer won't go forward, but MMPIs as anti-inflammatory therapeutics for arthritis will remain in the pipeline (Nat. Biotechnol. 18, 821, 2000). Weir says BBIOY has enough money to last about 30 months, but is looking for outside investment in its antibiotic program.

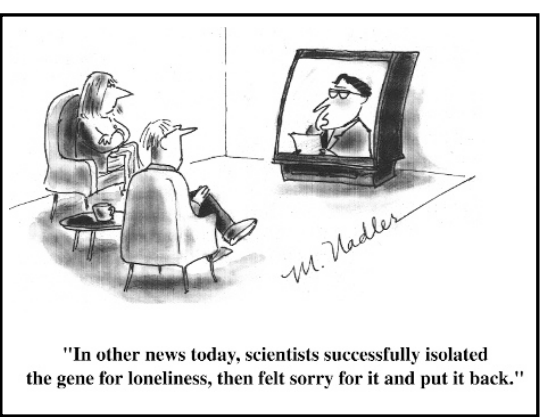

\section{Xenova and Cantab Merge}

On 19 February, two troubled UK-based biopharmaceutical companies, Xenova (Slough) and Cantab (Cambridge), announced plans to merge in an all-share deal valuing the combined biotechnology group at almost $£ 124$ million ( $\$ 182$ million). Cantab, whose shareholders will own a $50.2 \%$ stake in the new company, had been seeking a suitor following a series of setbacks culminating in the phase II failure in October of its vaccine for genital warts (Nat. Biotechnol. 18, 1238, 2000)—an event that triggered the resignation of its CEO Jurek Sikorski. Xenova came under pressure to seek a merger in June 2000 when its lead drug XR5000, a topoisomerase inhibitor, proved ineffective in phase II trials in colon cancer. Shares in both companies dropped following the news of the mergerXenova's $13 \%$ to $77.5 \mathrm{p}$ and Cantab's $2.5 \%$ to $117 \mathrm{p}$-signifying investor displeasure with the deal. Analysts point out that the two companies have different approaches for developing therapeutics-Xenova's oncology-based small molecules and Cantab's manipulation of the immune system to develop vaccines for infectious disease and cancers. But they say success of the merged company's seven products (that are currently in phase I and II trials) would quell these reservations.

$S D$

\section{Igen accused of nepotism}

Diagnostic and reagent firm Igen International (Gaithersburg, MD) has been hit with a shareholder's lawsuit claiming that too much of the company's money and resources have gone into private ventures run by Igen's CEO and his family in acts of nepotism, cronyism, and breach of fiduciary duty. The primary allegation is that Igen's corporate officials wasted over $\$ 15.1$ million during a fruitless five-year collaboration to develop a new microarray system with Meso Scale Technologies (Dover, DE), a private firm run by Jacob Wohlstader, son of Igen chair and CEO Samuel Wohlstadter. Steve Push, Igen's director of investor relations, says the lawsuit "is without merit and the officers and directors will defend themselves vigorously." While the collaboration has not yet resulted in any products, Push says that Meso Scale is still developing surface chemistry technology that may be useful. On April 20, an independent committee of Igen's board of directors will make a final decision about whether to continue the venture; none of the Wohlstader family members are on that committee. 